\title{
Commercial cultivars and farmers' access to crop diversity: A case study from the Nordic region
}

\author{
Svein Øivind Solberg ${ }^{1}$ and Line Breian ${ }^{2}$ \\ ${ }^{1}$ Nordic Genetic Resource Center, Box 41, 23053 Alnarp, Sweden \\ ${ }^{2}$ University of Gothenburg, Department of Philosophy, Linguistics and Theory of Science, Box 100, S-405 30 Gothenburg, \\ Sweden \\ email: svein.solberg63@gmail.com
}

\begin{abstract}
Agricultural diversification is one way of meeting the future challenges associated with climate change and population growth, making farmers' access to a diversity of high-yielding, good quality cultivars critical. In this paper we provide an overview of the seed system in the Nordic region from the 1950 to the present. The emphasis is on breeding businesses and their production of cultivars. Key primary sources have been the national variety lists, other written sources on plant breeding, and a survey. We document how enterprises have merged and how this consolidation process has affected the production of new cultivars and led to an emphasis on major crops, resulting in the abandonment of breeding activities for several other crops. The results are discussed in relation to structures and in the broader context of agrobiodiversity issues in peripheral regions of the world.
\end{abstract}

Key words: agriculture, agrobiodiversity, climate change, periphery, plant breeding, practice story, seed system, variety list, vegetables, trade, UPOV

\section{Introduction}

Access to good quality, high-yielding cultivars matters not only to farmers, but to society as a whole. Today, population growth, environmental pollution and climate change are major global challenges. Notwithstanding the immense challenges in this context, agriculture needs to produce more food, but with less environmental impact and under unpredictable climatic conditions (Hassol 2004, Nierenberg 2013, Betts and Hawkins 2014). Diversity in genetic combinations of seeds has been identified as important to a more systemic approach to climate change adaptation (Subbarao et al. 2005). Here, heterogeneous rather than homogeneous principals are potential solutions (Marshall 1977). Farmers have been selecting and saving seeds for thousands of years, domesticating and adapting crops to new growing conditions. Cereals, vegetables and other crops have been bred to meet human needs. The first dominant breeding method was line selection, but in the early twentieth century crossing methods were introduced, resulting in increased yields (Nilsson-Ehle 1906, Åkerman et al. 1951). Technological development has continued and farmers have become dissociated from the crop improvement process, where a limited number of transnational pharmaceutical or chemical corporations have grown at the expense of farmer cooperatives and of small family businesses (Schimmelpfennig et al. 2004, Fernandez-Cornejo and Just 2007, Howard 2009). However, global trends may not be uniform everywhere, all the less so in a peripheral region such as the Nordic countries. In this paper, emphasis is on farmers' access to relevant cultivars and the practice of plant breeding that produces these cultivars. In light of climate change this includes access to genetic material, facilitating a heterogeneous cropping system. Although we are aware of the complexity of the seed system and the political economy involved, we try to provide an overview of developments in the Nordic countries. We document how structures in our region have changed and how farmers' access to nationally or regionally bred cultivars has decreased gradually and even disappeared entirely for some crops. Simply replacing such cultivars with imported cultivars from regions further south yet being able to compete on an open market may not be an option. We argue for the importance of locally adapted high-yielding cultivars of a range of different crops and provide an account of the situation from the 1950s to the present. Breeding/seed enterprises (framed here as agents), new cultivars (framed as practice) and important structures are identified and analyzed; major changes are identified and discussed. The study attempts to: (1) overview the present practice and agents and (2) overview past practice and agents and analyze developments since. The emphasis is on the Nordic countries and on Sweden in particular, both because the Nordic countries and Sweden have had and continue to have extensive plant breeding activities, but also because we are located in a peripheral region of the world. Trends identified in this study would be relevant for similar geographic regions. 


\section{Material and methods \\ Concepts and framework}

The theory of practice stories, as described and applied by Karen O'Reilly (2012) which builds on structuration theory (Giddens 1984, Stones 2005), serves as a framework for the overview. Key concepts are external structures, internal structures, agents and their practices, and outcomes.

External structures refer to factors that influence the activity/practice of an agent, either at an upper, structural layer (global forces) or at more proximate layers (closer to the agents and more open to influence). Internal structures refer to what in the minds of the agents and in their perceptions of the situation. Internal structures include habitus (dispositions) and more proximate internal structures as acting or knowing or learning. Both external and internal structures create constraints on and opportunities for action/practice - in our case related to plant breeding. Agents or communities of agents are plant-breeding enterprises, institutions or networks engaged in plant breeding.

Over time, these practices are reshaping the more proximate external and internal structures, a process termed outcome in this study (Fig. 1). Applied to plant breeding and seed systems, the outcomes can be seen for example as changes in seed regulations. The outcome can be any large or small change; it is of a temporary nature, open to possibilities of further changes when new practices emerge.

Plant breeding is carried out in various settings, in historically perspectives by farmers and gardeners' communities, but nowadays mostly in national or international breeding enterprises, in governmental institutions or partnerships including research, breeding and seed industry. These are key agents or communities of agents. In addition, farmers and farmers' communities and governmental bodies are important stakeholders in the seed system, representing the market of cultivars and regulating the market.

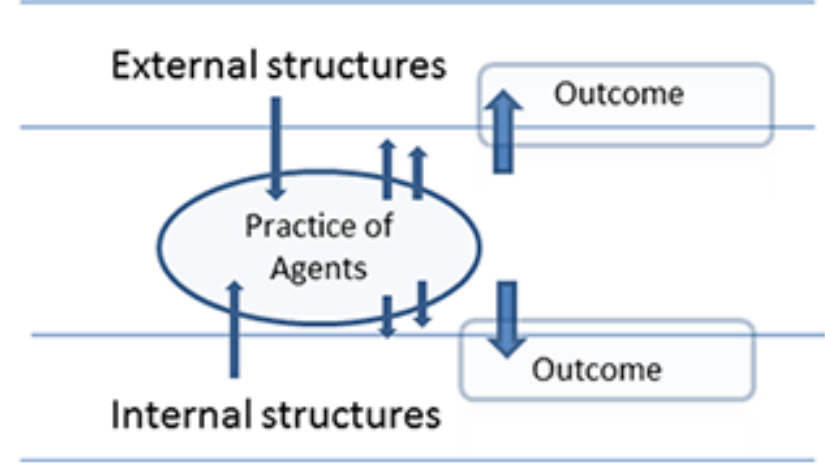

Fig. 1. Illustration of a conceptual model of the study

\section{Data gathering process}

National variety lists were used to extract information on agents and practices. The name and number of breeding enterprises and the number of listed cultivars are key measures in this overview. The main objective of plant breeding is the creation of a new commercial cultivar, and records on listed cultivars and enterprises are easily available, also historically, for past cultivars and enterprises. Primary sources for current developments are the last official national variety lists from Denmark (Naturerhvervstyrelsen 2014), Norway (Norwegian Food Safety Authority 2014), Finland (Evira 2014), Iceland (Landbúnađarháskóli Î́lands 2014), and Sweden (Official Swedish List of Cultivars 2014). Additional primary sources for the description of the current seed system were the enterprises' homepages and a stakeholder survey. An online stakeholder survey conducted in 2013 was used to gather information on how diverse groups of stakeholders view the cultivar situation. A number of different claims related to plant breeding and farmers' access to varieties with emphasis on the Arctic sub-region within the Nordic countries were presented (Solberg et al. 2014). As day length and temperature requirements makes the import of cultivars from central Europe impossible, the Arctic region faces particular constraints in its access to good cultivars. Key institutions - comprehending plant breeding enterprises, research institutes, farmers' organizations, authorities, NGOs, and others - were invited to participate. 
Using Google Form, the survey was sent via an email link to 95 key individuals in these institutions. A total of 45 respondents completed the survey, giving a response rate of less than $50 \%$. Despite the low total number of respondents, the survey was regarded as useful because of the key roles of those who were invited. The response to the various claims was given on a scale from $1=$ strongly agree to $5=$ strongly disagree.

Primary sources for the historical overview are records of listed cultivars from the National Plant Variety Board in Sweden (Official Swedish List of Cultivars 1952, 1960, 1970, 1980, 1990, 2000, 2007, 2013). These years were selected to cover the time span from the present to the establishment of common national variety lists in Sweden in the early 1950s (Official Swedish List of Cultivars 1952). Additional primary sources for the study of vegetables were the annuals from the official Swedish classifying trials (Lamm et al. 1945, 1952, 1957, 1960 and 1963). After 1963, the annuals for vegetables were incorporated in the National Plant Variety Board's official national variety list. Records for the cultivation area were taken from countries' official statistics: Swedish Board of Agriculture (2008, 2013a), Official Statistics of Finland (2014), Statistics Norway (2011), Danish Agriculture and Food Council (2014), and Statistics Iceland (2014) respectively.

Other sources used are articles and books, and these were used to identify important external structures. The Swedish Seed Association Journal was a key source, with the work of Nilsson and von Bothmer (2010a), Henriksson (2010) and Kraft (2010) representing key articles. Furthermore, the book "Den svenska växtförädlingens historia" with the chapters by Farjesson (1997), Olsson (1997), Persson (1997), and Sjödin (1997) and the book "Svensk växtförädling" (edited by Åkerman et al. 1951), with the chapter on institutions and private enterprises in Swedish plant breeding (Fröier 1951) were key sources.

\section{Data analysis and interpretation}

The relevance of national variety lists as a measure for farmers' access to cultivars was checked by matching the Swedish national variety list in 2013 with the overview of certified seed trade in Sweden in 2012/13 and 2013/14 (Swedish Board of Agriculture 2013b; 2014). The matching indicated that $73 \%$ of the listed forage legume cultivars have been traded, while the share for forage grasses is $70 \%$; $54 \%$ for cereal, $50 \%$ for pulses and $40 \%$ for oil crop cultivars. In addition, farmers have access to cultivars which are listed in other EU member countries and have been imported to the Nordic countries. In Sweden, more than 100 such cultivars are traded annually, albeit many of these in very limited amounts. Farmers' access to cultivars is therefore higher than is indicated by the national list alone; however, the access to relevant cultivars may not be as high. In addition, cultivar diversity must be considered in interpreting these numbers. A high number does not necessarily imply a high level of diversity. For example, most of the hundreds of oilseed rape (Brassica napus var. olifera) cultivars listed in Denmark are hybrids, not necessarily with very high diversity. We would assume that public breeders (in the past) were more careful when releasing and registering a cultivar than private enterprises are today.

Once identified, agents and structures were analyzed, applying qualitative content analysis and qualitative case study methods. In the analyses, interaction between agent and structure plays a central role and the ways in which this interaction influenced breeding practice and cultivar production. Content analysis is described as a process of identifying patterns or themes. This form of analysis was especially useful for the identification of essential structures. A qualitative case study method is an intensive investigation of a single unit of the study. This was especially useful for the investigation of historical Swedish plant breeding. Statistical analyses of numeric data were carried out by applying R software (R Core Team 2014). Tables were prepared to present the number of listed cultivars in a given year for the various crops, and the number of cultivars within each crop group was compared to cultivation area. Regression analyses were performed to analyze trends over time. Unless otherwise indicated, a linear model with $95 \%$ significance level was applied.

\section{Results}

\section{Current enterprises and commercial cultivars}

In this section, emphasis is on mapping existing enterprises and their production of commercial cultivars in the Nordic countries. We also detail the results of the stakeholders' perception, concentrating on results from the Arctic region. 


\section{Enterprises and cultivars}

Table 1 shows the enterprises or institutes and their respective crops with ongoing plant breeding programmes in the Nordic countries. Most of these businesses are majority-owned by either farmer communities or local funds (Lantmännen SW, DLF Trifolium, Sejet, Nordic Seed, LKF Vandel), or by the national state (Boreal and Graminor). In some instances breeding is done in a governmental institution (Swedish University of Agricultural Sciences, MTT Agrifood, Agricultural University of Iceland). Large transnational companies with combined chemical and seed business are represented in the region by Syngenta Seeds, who mostly breed sugar beet (Beta vulgaris var. altissima). A few years ago Syngenta acquired the Danish company Maribo, and Daehnfeldt; breeding of sugar beet, however, was moved to Sweden, and vegetable breeding to other countries. Most of the Nordic breeding enterprises have collaborations or partnerships with enterprises outside the region, most commonly with larger companies in France, the Netherlands and Germany.

Table 1. Overview of plant breeding for food and agriculture in Sweden, Denmark, Finland, Norway and Iceland in 2014 (only breeding programmes carried out in the Nordic area are included, micro-companies do exist and are listed in the footnote)

\begin{tabular}{|c|c|c|}
\hline Country & nterprise/Institute & Crops \\
\hline Swec & $\begin{array}{l}\text { Syngenta Seeds } \\
\text { Findus } \\
\text { Swedish University of } \\
\text { Agricultural Sciences }\end{array}$ & $\begin{array}{l}\text { Barley (spring type) (Hordeum vulgare), oat (Avena sativa), winter wheat (Triticum } \\
\text { aestivum), spring wheat, spring oilseed rape, forage grasses, red clover (Trifolium } \\
\text { pratense), white clover (T. repens), lucerne (Medigaco sativa) } \\
\text { Sugar beet } \\
\text { Wrinkled pea (Pisum sativum) } \\
\text { Potato (Solanum tuberosum), fruit, berries }\end{array}$ \\
\hline Denmark $^{2}$ & $\begin{array}{l}\text { Carlsberg } \\
\text { Sejet Plant Breeding } \\
\text { Nordic Seed } \\
\text { DLF Trifolium } \\
\text { LKF Vandel }\end{array}$ & $\begin{array}{l}\text { Barley (spring type) } \\
\text { Barley (both spring and winter types), winter wheat } \\
\text { Barley (spring and winter types), winter wheat } \\
\text { Forage grasses, red clover, white clover, fodder beet (Beta vulgaris) } \\
\text { Potato }\end{array}$ \\
\hline Finland & MTT Agrifood & $\begin{array}{l}\text { Barley, oat, rye, spring wheat, winter wheat, spring turn } \\
\text { campestris), field pea, faba bean (Vicia faba), potato, } f \\
\text { Research breeding on fruit and berries }\end{array}$ \\
\hline Norway $^{3}$ & Graminor & $\begin{array}{l}\text { Barley, oat, spring wheat, potato, forage grasses, red clover, white clover, lucerne, } \\
\text { fruits and berries }\end{array}$ \\
\hline Iceland & $\begin{array}{l}\text { Agricultural University of } \\
\text { Iceland }\end{array}$ & Barley, timothy (Phleum pratense), white clover \\
\hline \multicolumn{3}{|c|}{$\begin{array}{l}\text { 1. In Sweden: TD Förädling is a micro-company that continues to have field pea on the variety list in 2014. In addition there is participatory } \\
\text { breeding among organic farmers. In Denmark: Maribo seeds still continue to be listed with sugar beet, fodder beet, field pea, wrinkled } \\
\text { pea. They were a large player, but breeding has moved to other partners in the Syngenta group. In Denmark, Toft Plant Breeding was also } \\
\text { important and continues to have field pea, faba bean listed in 2014, but breeding has stopped. Of micro enterprises there are Bio-Plant/ } \\
\varnothing \text { lgaard with breeding on leek (Allium porrum) and cabbage (Brassica oleracea), Eghøjgaard on narrow leaved lupin (Lupinus angustifolius), } \\
\text { Knold\&Top on swede (Brassica napus var. napobrassica) and oil seed rape, Reffstrup on hop (Humulus lupulus), Kallehave on apple (Malus } \\
\text { domestica) and pear (Pyrus communis) and the participatory cereal breeding amongst the organic farmers. }{ }^{3} \text { In Norway: breeding of swede } \\
\text { is still to some extent carried out in an agricultural school in northern Norway. }\end{array}$} \\
\hline
\end{tabular}

Table 2 shows the number of cultivars on the national variety lists and sorted by crop groups. Both the number of nationally bred cultivars and the number of cultivars bred in other countries, but listed in the country, are given as well as the nation's cultivated area of that type of crops. Except for Sweden, the number of nationally bred cultivars on the national variety list is lower than the corresponding number from other countries. Figure 2 illustrates the cultivar exchange among the Nordic countries, but also the large-scale import of cultivars from other European countries. The illustration shows that importation from Germany, the Netherlands and France is greater than the number of Nordic exchanges. Hybrid cultivars completely dominate among sugar beet and oil crops, as well as among numerous vegetable crops like cauliflower (Brassica oleracea var. botrytis), cucumber (Cucumis sativus) and tomato (Lycopersicon esculentum), a situation that has remained unchanged since the 1980 s. Hybrid cultivars of rye have more recently entered the Nordic market, and around $50 \%$ of the rye cultivars are now hybrids. No genetically modified cultivar for food production has been listed in the Nordic countries except for one cultivar of fodder sugar beet (Beta vulgaris ssp. vulgaris var. alba) in Denmark. 
S. $\varnothing$. Solberg \& L. Breian (2015) 24: 150-163

Table 2. Number of cultivars bred in the country and listed on respective national variety list in $2014^{1}$ (in parenthesis is the numbers bred in other countries but listed on the respective national variety list) and cultivation area and number of cultivars per 1000 ha

\begin{tabular}{|c|c|c|c|c|c|c|}
\hline Crop group & Details & Finland & Norway & Denmark & Sweden & Iceland \\
\hline \multirow{3}{*}{$\begin{array}{l}\text { Oil and fibre } \\
\text { crops }^{6}\end{array}$} & Number of cultivars (sum) & 15 (19) & $0(8)$ & $2(140)$ & $19(9)$ & $0(3)$ \\
\hline & Cultivation area (in 1000 ha) & 53 & 5,5 & 176 & 110 & - \\
\hline & National bred cultivars per 1000 ha & 0.28 & 0 & 0.01 & 0.17 & - \\
\hline Sugar beet & Number of cultivars (sum) & $1(2)$ & $6(3)$ & $28(46)$ & $15(17)$ & $2(4)$ \\
\hline and other & Cultivation area (in 1000 ha) & 12 & - & 45 & 39 & - \\
\hline root crops & National bred cultivars per 1000 ha & 0.08 & - & 0.62 & 0.38 & - \\
\hline \multirow[t]{3}{*}{ Potato } & Number of cultivars (sum) & $10(29)$ & $21(35)$ & $21(41)$ & $7(10)$ & $2(3)$ \\
\hline & Cultivation area (in 1000 ha) & 23 & 12,7 & 40 & 24 & - \\
\hline & National bred cultivars per 1000 ha & 0.43 & 1.65 & 0.53 & 0.29 & - \\
\hline \multirow{3}{*}{ Cereals $^{7}$} & Number of cultivars (sum) & 70 (119) & $33(33)$ & 70 (99) & $60(19)$ & $3(28)$ \\
\hline & Cultivation area (in $1000 \mathrm{ha}$ ) & 1194 & 292 & 1435 & 1000 & 5,3 \\
\hline & National bred cultivars per 1000 ha & 0.06 & 0.11 & 0.05 & 0.06 & 0.57 \\
\hline \multirow{3}{*}{ Pulses $^{5}$} & Number of cultivars (sum) & 7 (9) & $0(2)$ & $10(9)$ & $7(1)$ & $0(5)$ \\
\hline & Cultivation area (in $1000 \mathrm{ha}$ ) & 12,3 & - & 8 & 40 & - \\
\hline & National bred cultivars per 1000 ha & 0.57 & - & 1.25 & 0.18 & - \\
\hline \multirow{3}{*}{$\begin{array}{l}\text { Forage } \\
\text { legumes }^{3}\end{array}$} & Number of cultivars (sum) & $4(10)$ & $17(7)$ & $7(3)$ & $21(2)$ & $0(14)$ \\
\hline & Cultivated meadow area (in $1000 \mathrm{ha}$ ) & 465 & 476 & 566 & 1177 & 89 \\
\hline & National bred cultivars per 1000 ha & 0.008 & 0.036 & 0.012 & 0.017 & 0 \\
\hline \multirow{3}{*}{$\begin{array}{l}\text { Forage } \\
\text { grasses }^{4}\end{array}$} & Number of cultivars (sum) & $24(39)$ & $29(43)$ & $19(10)$ & $28(9)$ & $3(45)$ \\
\hline & Cultivated meadow area (in $1000 \mathrm{ha}$ ) & 465 & 476 & 566 & 1177 & 89 \\
\hline & National bred cultivars per 1000 ha & 0.052 & 0.061 & 0.034 & 0.024 & 0.034 \\
\hline \multirow[t]{3}{*}{ Vegetables } & Number of cultivars (sum) & $0(0)$ & $8(1)$ & $20(75)$ & $16(8)$ & $0(0)$ \\
\hline & Cultivation area (in 1000 ha) & - & 7,1 & 10 & 16 & - \\
\hline & National bred cultivars per 1000 ha & - & 1.1 & 2.0 & 1.0 & - \\
\hline \multirow[t]{3}{*}{ Sum } & Number of cultivars (sum) & $131(227)$ & $114(130)$ & $177(423)$ & $173(75)$ & $10(100)$ \\
\hline & Cultivation area sum (in 1000 ha) & 1759 & 793 & 2280 & 2399 & 94 \\
\hline & National bred cultivars per 1000 ha & 0.07 & 0.14 & 0.08 & 0.07 & 0.11 \\
\hline
\end{tabular}

${ }^{1}$ For all countries: fruit and berries, turf grass and energy crops not included. Conservation varieties are not included. ${ }^{2}$ Root crops for Finland and Sweden include sugar beet and swede, for Norway fodder beet, forage rape (Brassica napus), swede and turnips (Brassica rapa subsp. rapa), for Denmark sugar beet and forage beet. ${ }^{3}$ Forage legumes include alsike- (T. hybridum), red- and white clover. In addition, vetch (Vicia sativa) included for Finland, and lucerne for Norway and Denmark. ${ }^{4}$ Forage grasses for Finland include cooksfoot (Dactylis glomerata), meadow fescue (Festuca pratensis), Festulolium (Festuca spp. X Lolium spp.), tall fescue (Festuca arundinacea), perennial ryegrass (Lolium perenne), smooth brome (Bromus inermis), Italian ryegrass (Lolium multiflorum ssp. italicum), Westervoldian ryegrass (Lolium multiflorum var. westerwoldicum) and timothy. For Norway the listed forage grasses are the same species except for smooth brome, but include red fescue (Festuca rubra) and three other species. ${ }^{5}$ Pulses in Finland include faba bean and field pea, in Norway only faba bean and in Denmark faba bean, field pea and narrow leaved lupine. ${ }^{6}$ Oil and fiber crops for Finland include spring rape seed, spring turnip rape, flax (Linum usitatissimum), common sunflower (Helianthus annuus), fiber-hemp (Cannabis sativa), and false flax (Camelina sativa), while in Norway only spring rape seed and spring turnip rape, and in Denmark winter and spring rape seed and caraway (Carum carvi). ${ }^{7}$ Cereals also including maize (Zea mays).

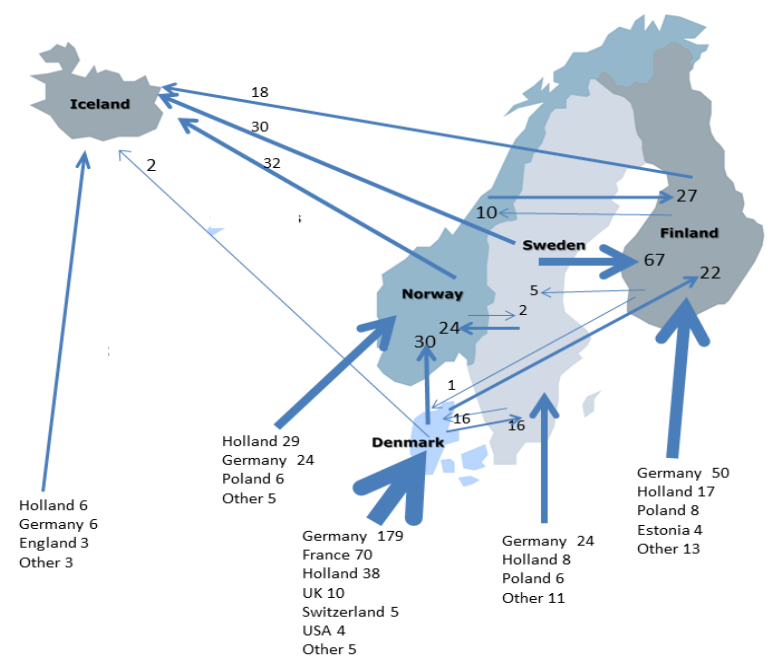

Fig. 2. Illustration of number of cultivars from other countries that are listed in a respective Nordic country based on information from the last national variety list in the country. Included in the numbers are all crops used as food and agriculture minus fruit and berries. 


\section{Stakeholders' survey in the Arctic region}

The survey on stakeholder perceptions of the situation indicates that the majority of the respondents in the Arctic region regard a lack of good cultivars as a constraint for Arctic food production (median score 2 on a scale from 1 to 5 , where 1 indicates "strongly agree"). Almost all responses strongly agreed or agreed with the claim that there is a need for new cultivars in the Arctic (median score = 1 on a scale from 1 to 5). Many agreed that re-introducing old cultivars (no longer on the variety lists) might be of interest (median score 2 on a scale from 1 to 5 ). Regarding variety testing, around $65 \%$ of the responses disagreed with the claim that there is proper variety testing in the region, that there is an official will/support for variety testing in the region, and that there is a will/ support from breeding enterprises/institutions for variety testing (all with median score 4 on a scale from 1 to 5 , where 5 is strongly disagree).

\section{Records from the past: Sweden as a case study Enterprises and cultivars}

Modern plant breeding in Sweden started in 1886 when farmers and landlords formed the Swedish Seed Association (Fröier 1951). At the same time, a marketing company, Allmänna Svenska Utsädedaktiebolag, was set up (Nilsson and von Bothmer 2010a). A few years later, W. Weibull AB was established (in 1870), focusing on seed production on tuber crops. A third company was established in 1907, Sockerbolaget, focusing mainly on sugar beet (Kraft 2010). AB Carl Engström was formed in 1926 to breed agricultural crops (Fröier 1951), and Algot Holmberg \& Söner AB followed in 1910; Otto J. Olsson in turn was formed in 1926 (Olsson 1997). In addition there vegetable breeding was carried out at J.E. Ohlsens Enke, at L. Daehnfeldts fröhandel , and at Statens Trädgårdsforsök in the 1930s and1940s. Breeding in fruits and berries started at Balsgård in 1941 (Fröier 1951).

Hilleshög Frö AB continued with sugar beet, first as part of Cardo, which was sold to Volvo in 1986, before being sold on first to Sandoz, then to Novartis, and finally to Syngenta in 2000. The Swedish Seed Association and Otto J. Olsson \& Son merged in 1971. In addition, the Swedish branch of Ohlsens Enke was included, as was the Danish branch of Ohlsens Enke a few years later also (Olsson 1997). In 1975 the Allmänna Svenska Utsädedaktiebolag formed Svalöf $A B, 50 \%$ state-owned, and a further $50 \%$ share owned by Lantmännen $A B$ (Nilsson and von Bothmer 2010a). W.Weibull AB had already bought Algot Holmberg \& Söner AB in 1966, and in 1992 Svalöf AB and W. Weibull $A B$ merged. By 1992 there only two breeding companies thus remained in Sweden: Svalöf Weibull $A B$ and Syngenta Seed AB. The Swedish state sold its shares. In 2005 the vegetable segment was closed. Today, Svalöf Weibull $A B$ is part of Lantmännen (as Lantmännen SW Seeds) marketing its products in more than 40 countries, with the other Nordic countries forming its primary market, followed by the Baltic countries, Germany and Poland (Gertson et al. 2010). In 2009, SW Winter Oilseed AB was established with SAS Maison Florimond Desprez, France and Elsoms Seeds Ltd, UK, exclusively focusing on winter oil seeds. Breeding and genetic research is carried out at the Swedish University of Agricultural Sciences, focusing on selected horticultural crops and potato (Henriksson 2010).

In Sweden, the number of listed cultivars from national breeding programmes has decreased since the 1950s (Table 3 and 4). However, on average the number per 1000 ha has been quite stable (as the cultivated area also is reduced). A reduction is evident for root crops other than sugar beet, for pulses, for red clover and for all types of vegetables. The reduction is clear, regardless of how we calculate (number of cultivars or number of cultivars per 1000 ha). For vegetables, some Danish cultivars that were also listed in Sweden are included in the numbers given. This is because the same enterprises were working in the two countries and had cultivars tested and listed both places, before subsequently merging. There has been extensive trade in Danish vegetable cultivars in Sweden. On the lists from 1952, 1960, 1970 and 1980, cultivars from Ohlsens Enke in Denmark dominated the Swedish vegetable lists together with cultivars from the Swedish enterprises W. Weibull and Hammenhög. In 1952 and 1960 the Swedish list contained only Swedish and Danish cultivars. If we look at the number of cultivars bred in other countries but listed in Sweden, the numbers have risen from the 1950s to the 1990s (results not shown), but have since declined. This latter development is a result of Sweden joining the EU in 1995, which resulted in legal changes that allowed the sale and use of cultivars listed in other EU countries in Sweden. 
Table 3. Agricultural crops; number of Swedish bred cultivars on the official variety lists from 1952 to 2013, and cultivation area and number of cultivars per 1000 ha

\begin{tabular}{|c|c|c|c|c|c|c|c|c|c|}
\hline & Crop & 1952 & 1960 & 1970 & 1980 & 1990 & 2000 & 2007 & 2013 \\
\hline \multirow[t]{10}{*}{ Oil crops } & Number of Swedish cultivars (sum) & 28 & 20 & 27 & 18 & 32 & 24 & 24 & 22 \\
\hline & Oil seed rape - winter & 3 & 4 & 9 & 5 & 7 & 8 & 7 & 6 \\
\hline & Oil seed rape - spring & 1 & 1 & 4 & 5 & 12 & 4 & 10 & 14 \\
\hline & Turnip rape & 2 & 7 & 5 & 4 & 9 & 10 & 7 & 2 \\
\hline & Poppy (Paper sp) & 1 & 1 & 1 & 1 & 1 & 1 & 0 & 0 \\
\hline & White mustard (Sinapis alba) & 9 & 1 & 2 & 1 & 1 & 1 & 0 & 0 \\
\hline & Flax & 10 & 5 & 5 & 2 & 2 & 0 & 0 & 0 \\
\hline & False flax & 2 & 1 & 1 & 0 & 0 & 0 & 0 & 0 \\
\hline & Cultivation area (in 1000 ha) & 179 & 68 & 96 & 177 & 168 & 59 & 92 & 110 \\
\hline & Oil crop cultivars per 1000 ha & 0,16 & 0,29 & 0,28 & 0,10 & 0,19 & 0,41 & 0,26 & 0,20 \\
\hline \multirow{3}{*}{$\begin{array}{l}\text { Sugar } \\
\text { beet }\end{array}$} & Number of Swedish cultivars (sum) & 0 & 0 & 3 & 20 & 13 & 9 & 11 & 12 \\
\hline & Cultivation area (in 1000 ha) & 54 & 50 & 40 & 52 & 50 & 55 & 41 & 39 \\
\hline & Sugar beet cultivars per 1000 ha & 0,00 & 0,00 & 0,08 & 0,38 & 0,26 & 0,16 & 0,27 & 0,31 \\
\hline \multirow{7}{*}{$\begin{array}{l}\text { Other } \\
\text { root } \\
\text { crops }\end{array}$} & Number of Swedish cultivars (sum) & 42 & 36 & 12 & 5 & 3 & 0 & 0 & 0 \\
\hline & Fodder beet & 16 & 14 & 5 & 2 & 1 & 0 & 0 & 0 \\
\hline & Fodder sugar beet & 13 & 14 & 4 & 2 & 1 & 0 & 0 & 0 \\
\hline & Fodder carrot (Daucus carota) & 1 & 0 & 0 & 0 & 0 & 0 & 0 & 0 \\
\hline & Turnips & 12 & 8 & 3 & 1 & 1 & 0 & 0 & 0 \\
\hline & Cultivation area (in 1000 ha) & 43 & 20 & 1 & 0,5 & 0,2 & 0,1 & 0,1 & 0,1 \\
\hline & Other root crop cultivars per 1000 ha & 0,98 & 1,80 & 12,00 & 10,00 & 15,00 & 0,00 & 0,00 & 0,00 \\
\hline \multirow[t]{3}{*}{ Potato } & Number of Swedish cultivars (sum) & 3 & 4 & 2 & 6 & 9 & 16 & 12 & 11 \\
\hline & Cultivation area (in 1000 ha) & 121 & 93 & 65 & 40 & 36 & 32 & 28 & 25 \\
\hline & Potato cultivars per 1000 ha & 0,02 & 0,04 & 0,03 & 0,15 & 0,25 & 0,50 & 0,43 & 0,44 \\
\hline \multirow[t]{8}{*}{ Cereals } & Number of Swedish cultivars (sum) & 89 & 61 & 65 & 65 & 63 & 62 & 68 & 57 \\
\hline & Oat & 26 & 16 & 18 & 13 & 18 & 18 & 15 & 13 \\
\hline & Barley & 23 & 18 & 19 & 31 & 27 & 31 & 21 & 21 \\
\hline & Wheat - winter & 17 & 10 & 10 & 8 & 11 & 4 & 12 & 12 \\
\hline & Wheat - spring & 15 & 12 & 15 & 11 & 6 & 6 & 10 & 6 \\
\hline & Rye & 8 & 5 & 3 & 2 & 1 & 3 & 10 & 5 \\
\hline & Cultivation area (in 1000 ha) & 1349 & 1453 & 1632 & 1604 & 1336 & 1229 & 990 & 1000 \\
\hline & Cereals cultivars per 1000 ha & 0,066 & 0,042 & 0,040 & 0,041 & 0,047 & 0,050 & 0,069 & 0,057 \\
\hline \multirow[t]{9}{*}{ Pulses } & Number of Swedish cultivars (sum) & 19 & 22 & 24 & 20 & 18 & 12 & 12 & 11 \\
\hline & Pea - dry types & 13 & 13 & 12 & 10 & 11 & 7 & 7 & 7 \\
\hline & Faba bean & 0 & 1 & 1 & 3 & 3 & 1 & 1 & 0 \\
\hline & Bean - dry types & 3 & 3 & 4 & 4 & 3 & 4 & 4 & 4 \\
\hline & Soya bean (Glycine max) & 0 & 2 & 2 & 1 & 1 & 0 & 0 & 0 \\
\hline & Common vetch & 2 & 2 & 4 & 2 & 0 & 0 & 0 & 0 \\
\hline & Narrow leaved lupine & 1 & 1 & 1 & 0 & 0 & 0 & 0 & 0 \\
\hline & Cultivation area (in 1000 ha) & 25 & 18 & 7 & 16 & 33 & 37 & 29 & 40 \\
\hline & Pulses cultivars per 1000 ha & 0,76 & 1,22 & 3,43 & 1,25 & 0,55 & 0,32 & 0,41 & 0,28 \\
\hline \multirow{7}{*}{$\begin{array}{l}\text { Forage } \\
\text { legumes }\end{array}$} & Number of Swedish cultivars (sum) & 44 & 36 & 34 & 28 & 26 & 23 & 19 & 20 \\
\hline & Red clover & 34 & 22 & 20 & 15 & 15 & 14 & 12 & 12 \\
\hline & White clover & 5 & 7 & 5 & 5 & 5 & 4 & 5 & 5 \\
\hline & Alsike clover & 3 & 4 & 4 & 3 & 2 & 1 & 1 & 1 \\
\hline & Lucerne & 2 & 3 & 5 & 5 & 4 & 4 & 1 & 2 \\
\hline & Cultivated meadow area (in 1000 ha) & 1484 & 1329 & 1031 & 914 & 929 & 925 & 1095 & 1177 \\
\hline & Forage legumes cultivars per 1000 ha & 0,030 & 0,027 & 0,033 & 0,031 & 0,028 & 0,025 & 0,017 & 0,017 \\
\hline
\end{tabular}


Table 3. continues

\begin{tabular}{|c|c|c|c|c|c|c|c|c|c|}
\hline \multirow{18}{*}{$\begin{array}{l}\text { Forage } \\
\text { grasses }\end{array}$} & Number of Swedish cultivars (sum) & 36 & 37 & 35 & 29 & 29 & 38 & 41 & 28 \\
\hline & Smooth brome & 1 & 1 & 1 & 1 & 1 & 0 & 0 & 0 \\
\hline & Field brome (Bromus arvensis) & 2 & 2 & 2 & 2 & 0 & 0 & 0 & 0 \\
\hline & Cooksfoot & 5 & 4 & 4 & 2 & 4 & 4 & 5 & 4 \\
\hline & Meadow fescue & 5 & 5 & 4 & 4 & 4 & 7 & 8 & 5 \\
\hline & Tall fescue & 0 & 0 & 0 & 0 & 0 & 0 & 1 & 1 \\
\hline & Swamp meadow-grass (Poa palustris) & 0 & 0 & 0 & 0 & 1 & 0 & 0 & 0 \\
\hline & Red fescue & 4 & 4 & 4 & 2 & 2 & 7 & 2 & 1 \\
\hline & Late meadow grass (Poa palustris) & 2 & 2 & 2 & 2 & 0 & 0 & 0 & 0 \\
\hline & Westerwold ryegrass & 0 & 0 & 0 & 2 & 0 & 1 & 2 & 2 \\
\hline & Italian ryegrass & 2 & 1 & 2 & 2 & 3 & 1 & 1 & 1 \\
\hline & Perennial ryegrass & 3 & 4 & 3 & 4 & 4 & 3 & 8 & 5 \\
\hline & Hybrid ryegrass (Lolium $x$ boucheanum) & 0 & 0 & 0 & 0 & 1 & 2 & 2 & 0 \\
\hline & Timothy & 8 & 8 & 7 & 6 & 6 & 10 & 9 & 7 \\
\hline & Smooth-stalked meadowgrass (Poa pratensis) & 4 & 6 & 5 & 2 & 3 & 3 & 3 & 2 \\
\hline & Red top (Agrostis gigantea) & 0 & 0 & 1 & 0 & 0 & 0 & 0 & 0 \\
\hline & Cultivated meadow area (in 1000 ha) & 1484 & 1329 & 1031 & 914 & 929 & 925 & 1095 & 1177 \\
\hline & Forage grasses cultivars per 1000 ha & 0,024 & 0,028 & 0,034 & 0,032 & 0,031 & 0,041 & 0,037 & 0,024 \\
\hline \multirow[t]{3}{*}{ SUM } & Number of cultivars & 261 & 216 & 202 & 191 & 193 & 184 & 187 & 161 \\
\hline & Cultivation area (in 1000 ha) & 3255 & 3031 & 2872 & 2804 & 2552 & 2337 & 2275 & 2391 \\
\hline & Swedish cultivars per 1000 ha & 0,080 & 0,071 & 0,070 & 0,068 & 0,076 & 0,079 & 0,082 & 0,067 \\
\hline
\end{tabular}

Table 4. Vegetables; number of Swedish bred cultivars on the official variety lists from 1952 to 2013, and cultivation area and number of cultivars per 1000 ha

\begin{tabular}{|c|c|c|c|c|c|c|c|c|}
\hline Vegetable crop & 1952 & 1960 & 1970 & 1980 & 1990 & 2000 & 2007 & 2013 \\
\hline Pea - vegetable types & 43 & 36 & 18 & 4 & 4 & 2 & 5 & 6 \\
\hline Bean - vegetable types & 26 & 18 & 19 & 9 & 0 & 0 & 0 & 0 \\
\hline Broad bean (V. faba var. $f a b a$ ) & 1 & 1 & 0 & 0 & 0 & 0 & 0 & 0 \\
\hline Cabbages & 40 & 39 & 44 & 24 & 14 & 11 & 4 & 6 \\
\hline Onion (Allium cepa) & 6 & 7 & 7 & 6 & 3 & 2 & 1 & 0 \\
\hline Leek & 6 & 5 & 6 & 5 & 8 & 7 & 3 & 1 \\
\hline Carrot & 21 & 23 & 23 & 21 & 14 & 5 & 5 & 1 \\
\hline Parsnip (Pastinaca sativa) & 6 & 6 & 5 & 2 & 2 & 0 & 0 & 0 \\
\hline Parley (Petroselinum crispum) & 7 & 8 & 8 & 6 & 5 & 1 & 0 & 0 \\
\hline Radish (Raphanus sativus) & 19 & 34 & 29 & 10 & 11 & 2 & 3 & 0 \\
\hline Garden beet (B.v. var. conditiva) & 12 & 10 & 12 & 7 & 6 & 4 & 3 & 2 \\
\hline Celery (Apium graveolens) & 4 & 3 & 3 & 1 & 1 & 0 & 0 & 0 \\
\hline Dill (Anethum graveolens) & 2 & 5 & 8 & 4 & 5 & 2 & 0 & 0 \\
\hline Lettuce (Lactuca sativa) & 11 & 8 & 6 & 2 & 5 & 1 & 2 & 1 \\
\hline Spinach (Spinacia oleracea) & 18 & 22 & 11 & 2 & 5 & 2 & 1 & 0 \\
\hline Tomato & 16 & 14 & 8 & 2 & 5 & 2 & 3 & 1 \\
\hline Cucumber/gherkin (Cucumis sp.) & 36 & 26 & 22 & 14 & 11 & 5 & 2 & 2 \\
\hline Melon (Cucumis melo) & 9 & 5 & 3 & 1 & 1 & 1 & 1 & 1 \\
\hline Sweet pepper (Capsicum annuum) & 0 & 0 & 1 & 1 & 1 & 0 & 0 & 0 \\
\hline Number of Swedish cultivars (sum) & 283 & 270 & 233 & 121 & 101 & 47 & 33 & 21 \\
\hline Cultivation area (in 1000 ha) & 8,6 & 10,7 & 12,8 & 12 & 11 & 10,4 & 14,9 & 15 \\
\hline Swedish cultivars per 1000 ha & 32,9 & 25,2 & 18,2 & 10,1 & 9,2 & 4,5 & 2,2 & 1,4 \\
\hline
\end{tabular}


In Sweden, plant breeding in several agricultural crops has ceased since the 1960s, putting an end to breeding in six species of pulses, (soya bean, faba bean, common vetch, narrow leaved lupine, dry bean, both field and soup peas), three species of root crops (swede, turnips, fodder beet), six forage grass species (smooth brome, field brome, swamp meadow-grass, late meadow grass, hybrid ryegrass, redtop) and five oil and fibre crops (white mustard, flax, false flax, fibre-hemp, and poppy). Changes are even more dramatic for vegetable crops. Since the 1960s, breeding has been discontinued in eighteen vegetable species (common bean, broad bean, cabbage, onion, leek, carrot, parsnip, parsley, radish, garden beet, celery, dill, lettuce, spinach, tomato, cucumber, melon, and sweet pepper) and today breeding activity continues only for a single species (wrinkled pea). Vegetable breeding is also very limited in the other Nordic countries.

\section{Agent and structure interactions}

In this section we will identify how external structures have influenced plant breeding in Sweden. At an upper structural layer, globalization and the EU's common market as well as new molecular methods in plant breeding were identified as important for the Swedish case. At a more proximate layer, governmental support, the International Union for the Protection of New Varieties of Plants (UPOV 2014), plant breeders' right and official variety lists and control were identified as keys (Fig. 3).

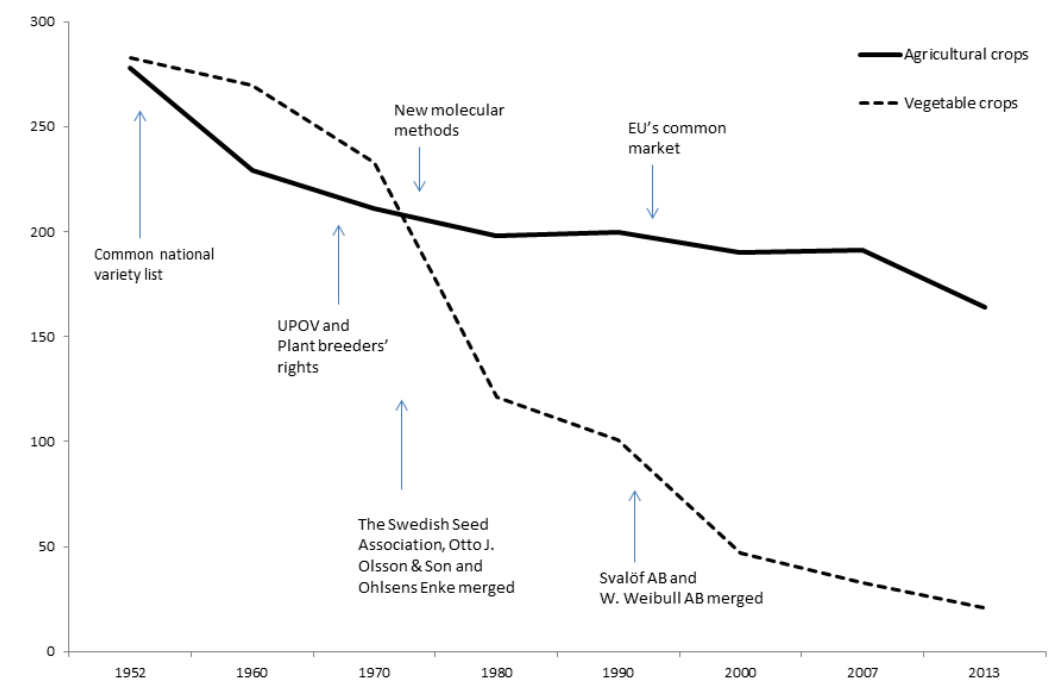

Fig. 3. Illustration of the number of nationally bred cultivars of agricultural crops and vegetables that were listed in Sweden from the 1950s onwards, and with contemporary important external and internal structures

From an early point in time the Swedish government demonstrated its awareness of the value of plant breeding, while also being acquainted with the economic challenges associated with breeding practice. Already a few years after the establishment of the Swedish Seed Association, financial support was given to the association (Nilsson and von Bothmer 2010a). Later, in the 1920s, W. Weibull AB also had to request funding from the Swedish government (Fajersson 1997). At this time, plant breeding was a relatively new practice; farmers still tended to save seeds and use the old local varieties (landraces). The idea of a royalty system as opposed to governmental funding, was proposed by Weibull as early as in 1948 (Fajersson 1997). This is a good example of structure-agent interaction. At that time Gunnar Weibull was the president of ISSINSEL (The International Association for Plant Breeding Companies). ISSINSEL suggested an international convention for plant breeders' rights, a convention that became a reality in Paris in 1961 and formed the basis for UPOV. Official variety tests and controls are important components of the seed system. In 1924, an official seed-testing system had already been set up in Sweden (Statens Centrala Frökontrollantalt) (Fajersson 1997) and in England (Mackay et al. 2011), which served as an example. The guiding objective was to protect farmers by avoiding the need for trade with cultivars not suitable for the country but also to secure seed quality. Field trials were conducted to test the cultivars and information was made available to farmers. In Sweden, a joint official national variety list for all crops was established in 1951 (Kungl. Lantbruksstyrelsen kungörelse Nr. 4, 1951, 7§) (Official Swedish List of Cultivars 1952). Only listed and tested cultivars could be labeled as officially controlled. The label was a guarantee that the quality complied with national standards. Plant breeders' rights were fully implemented in Sweden in 1969, when the official variety list and control was expanded to also include aspects of plant breeders' rights. 


\section{Discussion \\ Reshaping structures (outcomes)}

This study outlines a consolidation in plant breeding activities and a reduction of activity in minor crops such as vegetables. The consolidation process is also illustrated in Figure 4, which focuses on vegetables. Globally, this is not a unique situation, and of the 392 vegetable crops cultivated, only half are given commercial attention in terms of breeding (Kays and Dias 1995). Our concern, however, is that Nordic breeding has ceased, also in major vegetable crops. Another crop group receiving little breeding attention are grain legumes. Nordic feed protein has been replaced by imported and cheaper (genetically modified) soya bean (Stoddard et al. 2009, Peltonen-Sainio and Niemi 2012). GM methods were discovered in the early 1970s (Cohen et al. 1973, Berg et al. 1974) but were not implemented in Europe as in the USA and South America (Jasanoff 2005). Some of the Nordic breeding communities invested into these techniques, especially in oilseed rape, but did not gain income and have hence suffered from this lack of development.

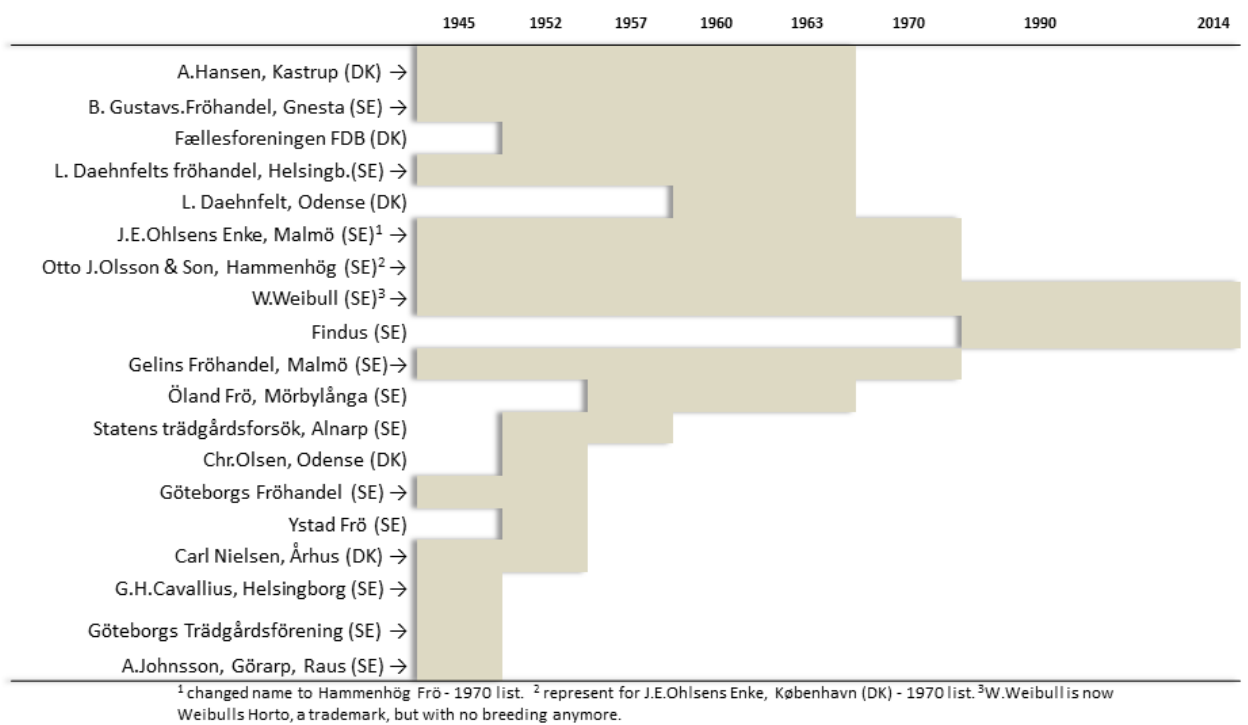

Fig. 4. Swedish and Danish seed enterprises with vegetable cultivars in the official variety trials/official variety list in Sweden from 1945 to 2014 (Lamm et al. 1945, 1952, 1957, 1960, 1963, Official Swedish List of Cultivars 1970, 1990, 2014)

Peripheralization (Kühn 2015) is a concept of relevance to this study, as the Nordic region encompasses the northernmost cultivation border for many crops in geographical terms. The ongoing process of withdrawing of crop development stands in contrast to the role of genetics in the state-led agricultural modernization efforts that took place in various industrialized countries during the 1920s and onwards (Flitner 2003). At that time, emphasis was on production of cultivars adapted to the various geographic and climatic conditions in the country, often on the basis of public funding. In 1950, the Swedish Seed Association alone had 23 research stations or sub-stations (Fröier 1951), now reduced to two (Henriksson 2010).

This change in structures is associated with factors that constrain self-sufficiency and renewable use of seed resources (Srinivasan, 2003, Mascarenhas and Busch 2006) and a shift towards the breeding of the most profitable crops and hybrids; these are not crops that farmers can replant (Kloppenburg 1988). The shift from plant breeding as a public responsibility to an activity that is regulated exclusively by the market raises questions of transparency and on the ways in which new knowledge is shared. Publishing research and work outcomes is part of the job description of public researchers in universities or research institutes, but in private enterprises new knowledge is not necessarily shared in the public domain. Education is another important aspect of these processes: how can universities educate future plant breeders if they do not engage in plant breeding? Learning by doing and an integration of theory and practice ought to be at the very heart of university education. The role of plant breeders in society at large is seen as focusing on adapting crops to sustainable production systems, and as supplying farmers with useful seeds (Peltonen-Sainio et al. 2008). However, in the periphery there is a need to reconsider the balance between public and private, not in order to move back in time, but to find new solutions and new ways of interacting. 
The rights of plant breeders have been identified as being significant, and this question has been included in the UPOV convention that was signed in 1968 (Jördens and Button 2011) and to which the Nordic countries became signatories some years later. A royalty,usually $15 \%$, is to be paid to the breeder in order to stimulate investment and production of new cultivars. This is a development documented by Santos et al. (2012), but contrasted by others (Fowler 1980, Kloppenburg 1988). A small royalty is to be paid also for farm-saved seeds and this has been, and continues to be a contentious topic (Andersen 2005), in part because marketing cultivars not listed on a variety list is prohibited (Borowiak 2004). Our study (Fig. 2) shows no increase in the numbers of listed cultivars after UPOV; in fact, our study indicates that a decrease has taken place, which may be explained by at least two developments. The first relates to the change in structures (as described). The second relates to UPOV and seed legalization. Before 1968, several landraces, especially of red clover and fodder grasses, as well as local enterprises' strains/selections were still listed and in use (Official Swedish List of Cultivars 1960). Such cultivars were no longer able to fulfill the DUS-criteria and had no official owner or maintainer, so almost all of them were removed from the Swedish list between 1970 and 1980 (Official Swedish List of Cultivars 1970, 1980). Such a negative impact of the seed legalization system on the use of landraces is also reported by Bocci (2009). A historical overview of the use of landraces in the Nordic agriculture is provided by Åkerman et al. (1951) and partly also by Bjørnstad (2010), indicating that landrace cultivation was greatly reduced in the early half of the twentieth century. Seed legalization, however, put an end to the landraces.

Plant breeding is a dynamic process, supported by a research sector, both private and public. Breeders at the European level strongly support public funding remaining at a competitive level and the existence of national and/or European programmes facilitating plant breeding that meets the ever-changing needs of farmers and of society at large (Neumann 2013, Frese et al. 2014). Public-private partnerships may represent a solution, where cooperation on pre-breeding is relevant (Nilsson and von Bothmer 2010b). So far, Nordic projects have only been carried out on a few crops such as barley, ryegrass and apple and not on minor crops. Pre-breeding is understood as a necessary first step in the use of diversity arising from wild relatives and landraces (Haussmann et al. 2004). Smaller companies have limited capacity for pre-breeding and often deal with niche crops or niche markets. By including these in pre-breeding, a wider diversity can be included in the breeding process and farming systems. Landraces are important for novel gene variants. In addition, they are valued for cultural heritage and culinary reasons as well as for local adaptation (Newton et al. 2010). By cultivating landraces, farmers maintain local knowledge and are involved in the conservation of seed biodiversity (Gepts and Hancock 2006, Vasconcelos et al. 2013). In the Nordic countries, farmers have started to re-cultivate these old varieties and old open-pollinated vegetable crops. To promote seed sales, the cultivars have been with provided specific legislation (EC 2008, 2009). The Swedish official variety list now includes more than fifty conservation varieties and varieties developed for growing under particular conditions. However, the system does not necessarily stimulate crop improvement. Li et al. (2014) have shown how novel cooperation between breeders and farmers can work in a participatory plant breeding and marketing arrangement in China, while also capturing incentives for farmers to conserve the traditional varieties. In the USA, an open source system for seeds has been launched to include legal mechanisms drawn from open source software movement, where free exchange of newly developed cultivars is made possible by cooperation among farmers, public breeders and small seed companies (Kloppenburg 2014).

\section{Diversity and the grand challenges}

The seed system may find itself at a cross-road. The consolidation of enterprises and the reduction of breeding programmes may continue, but the future may open up opportunities for new actors and new networks, both in the Nordic countries and globally. We identified a specific concern about farmers' access to relevant cultivars for food production in the Arctic. At the same time we identified substantial import of cultivars to the Nordic countries from other European countries. Whether the system with plant breeders' rights and a free market has expanded the range of choices open to farmers and gardeners in the entire Nordic region, can be answered in at least two different ways, depending on if you are in the peripheral (northern) or the central cultivation area (southern part of the region). The challenges today have changed relative to the situation 50 years ago. With the present increase in the emission of greenhouse gasses, the average global temperature will increase by $4-5^{\circ} \mathrm{C}$ by the end of this century (IPCC 2013), affecting all biological systems, including agro-ecosystems. Farmers and breeders must work for adaptation to scenarios that will result in more severe floods in our part of the world, as well as stronger winds, greater temperature fluctuations, but also increased disease pressure (Hassol 2004, Hakala et al. 2011, Olesen et al. 2011). Climate change is linked to complicated energy and economic scenarios, too. These considerable challenges necessitate a shift towards heterogenic but productive and resilient agro-ecosystems (Altieri et al. 2012, Constanzo and Bàrberi 2014). Access to adapted and high-yielding cultivars of a diversity of crops is part of the solution. Crop heterogeneity can also be addressed through a mixture of cultivars (Finckh et al. 2000) or the use of genetically heterogeneous populations (Phillips and Wolfe 2005, Haussmann et al. 2012). 
Regardless of the way of implementing diversity, cultivation and breeding of different species must be included in a strategy for food security under unpredictable environmental conditions (Marshall 1977, Malézieux et al. 2009, Silva 2010). We will say that the use of agro-biodiversity appears to be crucial, but that our case study has shown a concern with lack of breeding efforts on several crops. We would rather see technological innovations with the breeding of climate-resilient crop cultivars of a range of crops (Dwivedi et al. 2013). There is not one solution only. Breeding can go hand in hand with a system-approach, and together go along a robust pathway to meet the grand challenges of our time.

\section{References}

Altieri, M.A., Funes-Monzote, F.R. \& Petersen, P. 2012. Agroecologically efficient agricultural systems for smallholder farmers: contributions to food sovereignty. Agronomy for Sustainable Development 32: 1-13.

Andersen, R. 2005. The farmers' rights project - background study 2: Results from an international stakeholder survey on farmers' rights. FNI report 9. Oslo:The Fridtjof Nansen Institute. http://www.fni.no/doc\&pdf/FNI-R0905.pdf.

Berg, P., Baltimore, D., Boyer, H.W., Cohen, S.N., Davis R.W., Hogness, D.S. Nathans, D. Roblin, V., Watson, J.D., Weissman, S. \& Zinder, N.D. 1974. Potential biohazards of recombinant DNA molecules. Science 185: 303-303.

Betts, R.A. \& Hawkins, E. 2014. Climate projections. In: Jackson M. Ford-Lloyd, B., and Parry, M. (eds.). Plant Genetic Resources and Climate Change. Wallingford/Boston: CABI. p. 38-60.

Bocci, R. 2009. Seed legislation and agrobiodiversity: conservation varieties. Journal of Agriculture and Environment for International Development 103: 31-49.

Borowiak, C. 2004. Farmers' Rights: Intellectual Property Regimes and the Struggle over Seeds. Politics \& Society 32:511-543.

Bjørnstad, Å. 2010. Our daily bread. Oslo:Vidarforlaget. 272 p.

Cohen, S.N., Chang, A.C.Y., Boyer, H.W. \& Helling, R.B. 1973. Construction of biologically functional bacterial plasmids in vitro. Proceedings of the National Academy of Sciences of the United States of America 70: 3240-3244.

EC 2008. Commission Directive 2008/62/EC of 20 June 2008 providing for certain derogations for acceptance of agricultural landraces and varieties which are naturally adapted to the local and regional conditions and threatened by genetic erosion and for marketing of seed and seed potatoes of those landraces and varieties. The Official Journal of the European Union L 162:13-19.

EC 2009. Commission Directive 2009/145/EC of 26 November 2009 providing for certain derogations, for acceptance of vegetable landraces and varieties which have been traditionally grown in particular localities and regions and are threatened by genetic erosion and of vegetable varieties with no intrinsic value for commercial crop production but developed for growing under particular conditions and for marketing of seed of those landraces and varieties. The Official Journal of the European Union L 312:44-52.

Costanzo, A. \& Bàrberi, P. 2014. Functional agrobiodiversity and agroecosystem services in sustainable wheat production. A review. Agronomy for Sustainable Development 34:327-348.

Danish Agriculture and Food Council 2014. Facts and Figures, Danish agriculture and food 2014. http://www.agricultureandfood. dk/Prices_Statistics/Annual_Statistics.aspx.

Dwivedi, S., Sahrawat, K ., Upadhyaya, H. \& Ortiz, R. 2013. Food, nutrition and agrobiodiversity under global climate change. In: Sparks, D.L. (ed.). Advances in Agronomy. Agronomy, Academic Press, Elsevier Inc. p.1-128

Evira, 2014. Suomen Kasvilajiketiedote. Finnish Plant Variety Journal 2: 1-60.

Farjesson, F. 1997. Weibullsholm. Familieföretakets utveckling 1870-1980. In: Olsson G. (ed.). Den svenska växtförädlingens historia. Stockholm: Kungl.Skogs- och Lantbruksakademien. p. 35-50.

Fernandez-Cornejo, J. \& Just, R.E. 2007. Researchability of modern agricultural input markets and growing concentration. American Journal of Agricultural Economics 89: 1269-1275.

Finckh, M.R., Gacek, E.S., Goyeau H., Lannou, C., Merz, U., Mundt C.C., Munk, L., Nadziak, J., Newton, A.C.,DeVallavielle-Pope, C. \& Wolfe, M.S. 2000. Cereal variety and species mixture in practice, with special emphasis on disease resistance. Agronomie 20: 813-837.

Flitner, M. 2003. Genetic geographies. A historical comparison of agrarian modernization and eugenic thought in Germany, the Soviet Union, and the United States. Geoforum 34: 175-185.

Fowler, C. 1980. Sawing the seeds of destruction. Science for the people (September/October): 8-10.

Frese, L., Palmé, A. \& Kik, C. 2014. On the sustainable use and conservation of plant genetic resources in Europe. Report from Work Package 5 "Engaging the user Community" of the PGR Secure project "Novel characterization of crop wild relative and landrace resources as a basis for improved crop breeding". http://www.pgrsecure.bham.ac.uk/sites/default/files/documents/public/D7.3_PGR_Secure_3rd_periodic_and_final_report_consolidated_PU.pdf.

Fröier, K. 1951. Institutioner och privatföretag, som bedriva växtförädling i Sverige. In: Åkerman, Å., Nilsson, F., Sylvèn, N. \& Fröier, K. (eds.). Svensk växtförädling. Stockholm: Natur och Kultur. p. 699-729. (in Swedish).

Gepts, P. \& Hancock, J. 2006. The future of plant breeding. Crop Science 46: 1630-1634.

Gertson, B., Börjesdotter, D., \& Uppström, B. 2010. From field to fork - the chain starts at Lantmännen SW Seed. Journal of the Swedish Seed Association 117: 21-25. (in Swedish).

Giddens, A. 1984. The constitution of society: Outline of the theory of structuration. Oakland: University of California Press. $402 \mathrm{p}$.

Hakala, K., Hannukkala, A., Huusela-Veistola, E., Jalli, M \& Peltonen-Sainio, P. 2011. Pests and diseases in a changing climate: a major challenge for Finnish crop production. Agricultural and Food Science 20: 3-14. 
Hassol, S.J. 2004. Impacts of a warming Arctic: Arctic Climate Impact Assessment. Cambridge, UK: Cambridge University Press. 139 p. Haussmann, B.I.G., Parzies, H.K., Presterl, T., Sušic, Z. \& Miedaner, T. 2004. Plant genetic resources in crop improvement. Plant Genetic Resources: 3-21.

Haussmann, B.I.G., Rattunde, H.F., Weltzien-Rattunde, E., Traore P. S. C., Brocke, K. vom \& Parzies, H. K. 2012. Breeding strategies for adaptation of pearl millet and sorghum to climate variability and change in West Africa. Journal of Agronomy and Crop Science 198: 327-339.

Henriksson, P. 2010. Future demands for development of varieties for the Swedish market. How can we ensure continued plant breeding efforts of Swedish crop production? Journal of the Swedish Seed Association 117: 40-43. (in Swedish).

Howard, P.H. 2009. Visualizing consolidation in the global seed industry: 1996-2008. Sustainability 1: 1266-1287.

IPCC 2013. Climate Change 2013: The Physical Science Basis. The Intergovernmental Panel on Climate Change. https://www.ipcc.ch Jasanoff, S. 2005. 'Let them eat cake': GM foods and the democratic imagination. In: Leach, M., Scoones, I, \& Wynne, B. (Eds.). Science and Citizens: Globalization and the challenge of engagement. London: Zen Book Ltd. p. 183-198.

Jördens, R \& Button, P. 2011. Effective systems of plant variety protection in responding to challenges of a changing world: UPOV perspective. Journal of Intellectual Property Rights 16: 74-83.

Kays, S.J. \& Dias J.S. 1995. Common names of commercially cultivated vegetables of the world in 15 languages. Economic Botany 49:115-152.

Kloppenburg, J.R. 1988. First the seed. Cambridge: The press syndicate of the University of Cambridge. 468 p.

Kloppenburg, J. 2014. Re-purposing the master's tools: the open source seed initiative and the struggle for seed sovereignty. The Journal of Peasant Studies 41: 1225-1246.

Kraft, T. 2010. Syngenta. Journal of the Swedish Seed Association 117: 26-31. (in Swedish).

Kühn, M. 2015. Peripheralization: Theoretical Concepts Explaining Socio-Spatial Inequalities. European Planning Studies 23: 367-378.

Lamm, R., Tometorp, G., \& Åvall, H. 1945. Klassificerande försök med köksväxter. Meddelande från Statens Trädgårdsförsök 26 : 165-202. (in Swedish).

Lamm, R., Tometorp, G., \& Åvall, H. 1952. Klassificerande försök med köksväxter. Meddelande från Statens Trädgårdsförsök 73 : 1-29. (in Swedish).

Lamm, R., Tometorp, G., \& Åvall, H. 1957. Klassificerande försök med köksväxter. Meddelande från Statens Trädgårdsförsök 106 : 1-28. (in Swedish).

Lamm, R., Tometorp, G., \& Åvall, H. 1960. Klassificerande försök med köksväxter. Meddelande från Statens Trädgårdsförsök 136 : 1-24. (in Swedish).

Lamm, R., Tometorp, G., \& Åvall, H. 1963. Klassificerande försök med köksväxter. Meddelande från Statens Trädgårdsförsök 152 : 1-25. (in Swedish).

Landbúnađarháskóli Íslands, 2014. Nytjaplöntur á Íslandi.Reykjavik. 22 p. (in Iclandic).

Li, J., van Bueren E.T.L., Lesuvis, C. \& Jiggins, J. 2014. Expressing the public value of plant genetic resources by organizing novel relationships: The contribution of selected participatory plant breeding and market-based arrangements. Journal of Rural Studies 36: 182-196.

Mackay, I., Horwell, A., Garner, J., White, J., McKee, J. \& Philpott, H. 2011. Reanalyses of the historical series of UK variety trials to quantify the contributions of genetic and environmental factors to trends and variability in yield over time. Theoretical and Applied Genetics 122: 225-238.

Malézieux, E., Crozat, Y., Dupraz, C., Laurans, M., Makowski, D., Ozier-Lafontaine, H., Rapidel, B., De Tourdonnet, S. \& ValantinMorison, M. 2009. Mixing plant species in cropping systems: concepts, tools and models. A review. Agronomy for Sustainable Development 29:43-62.

Marshall, D.R. 1977. The advantages and hazards of genetic homogeneity. Annals of the New York Academy of Sciences 287: 1-20.

Mascarenhas, M. \& Busch, L. 2006. Seeds of change: intellectual property rights, genetically modified soybeans and seed saving in the United States. Sociologia Ruralis 46: 122-138.

Naturerhvervstyrelsen, 2014. The Official List of Varieties. The Danish Gazette for Plant Varieties 32: 1-36.

Neumann, C. 2013. Die Bedeutung der Züchtungsforschung an Kulturpflanzen. Journal für Kulturpflanzen 65: 253-261. (abstract in English).

Newton, A. C., Akar, T., Baresel, J. P., Bebeli, P. J., Bettencourt, E., Bladenopoulos, K. V., Czembor, J. H., Fasoula, D. A., Katsiotis, A., Koutis, K., Koutsika-Sotiriou, M., Kovacs, G., Larsson, H., Pinheiro de Carvalho, M. A. A., Rubiales, D., Russell, J., Dos Santos, T. M. M., \& Vaz Patto, M. C. 2010. Cereal landraces for sustainable agriculture. A review. Agronomy for Sustainable Development 30: $237-269$.

Nierenberg, D. 2013. Agriculture: Growing food - and solutions. In: Assadourian, E. \& Prugh, T. (eds.). State of the world. Is sustainability still possible? Washington/Covelo/London: Island Press. p. 190-200.

Nilsson, A. \& von Bothmer, R. 2010a. Is there a future for public plant breeding in Sverige? Journal of the Swedish Seed Association 117: 34-39. (in Swedish).

Nilsson, A. \& von Bothmer, R. 2010b. Measures to promote Nordic plant breeding - A proposal for increased Nordic collaboration in pre-breeding. Journal of the Swedish Seed Association 117: 59-65. (in Swedish).

Nilsson-Ehle, H. 1906. Något om korsningar och deras betydelse för föredlingsarbetena med höstvete. Journal of the Swedish Seed Association 16:309-318. (in Swedish).

Norwegian food safety authority 2014. The Norwegian official list of varieties, November 2013. Brummundal: The plant variety board/ Norwegian food safety authority. $22 \mathrm{p}$. 


\section{AGRICULTURAL AND FOOD SCIENCE}

S. Ø. Solberg \& L. Breian (2015) 24: 150-163

Official Statistics of Finland 2014. Crop Production Statistics. Natural Resources Institute. http://www.stat.fi/til/satot/index_en.html Official Swedish List of Cultivars 1952. Förteckning over sorter och stammar, som Orginalutsädesnämden som äro berättigad till statsplombering 1952-1953. Stockholm: Emil Kihlströms Tryckeri AB. 16p.

Official Swedish List of Cultivars1960. Rikssortlista - omfattande sorter och stammar, som Orginalutsädesnämden förklarats berättigade till statsplombering sesongen 1960-1961. Helsingborg: Schmidts Boktryckeri AB. 16p.

Official Swedish List of Cultivars 1970. Official Swedish list of cultivars 1970-1971. Helsingborg: Schmidts Boktryckeri AB. 39 p.

Official Swedish List of Cultivars 1980. Rikssortlista 1980-1981. Jönköping: National Plant Variety Board. 24 p.

Official Swedish List of Cultivars 1990. Sortlista 1990-1991 sorter godkända för statsplombering. Jönköping: National Plant Variety Board. 24. p

Official Swedish List of Cultivars 2000. Sortlista 2000, National list of plant varieties. Jönköping: National Plant Variety Board. 20 p. Official Swedish List of Cultivars 2007. Sortlista 2007, National list of plant varieties. Jönköping: National Plant Variety Board. 20 p. Official Swedish List of Cultivars 2013. Sortlista 2013, National list of plant varieties. Jönköping: National Plant Variety Board. 19 p. Official Swedish List of Cultivars 2014. National List of Plant Varieties 2014. Jönköping: National Plant Variety Board. 18 p.

Olesen, J.E., Trnka, M., Kersbaum, K.C., Skjelvåg, A.O. Seguin, B., Peltonen-Sainio, P., Rossi, F., Kozyra, J. \& Micale, F. 2011. Impacts and adaptation of European crop production systems to climate change. European Journal of Agronomy 34: 96-112.

Olsson, G. 1997. Otto J Olsson \& Son i Hammenhög. In: Olsson G. (ed.). Den svenska växtförädlingens historia. Stockholm: Kungliga Skogs- och Lantbruksakademien. p.77-80. (in Swedish).

O'Reilly, K. 2012. International migration and social theory. Basingstoke: Palgrave Macmillan. 200 p.

Peltonen-Sainio, P., Jauhiainen, L. \& Laurila, I. P. 2008. Cereal yield trends in northern European conditions: Changes in yield potential and its realisation. Field Crops Research 110:85-90.

Peltonen-Sainio, P. \& Niemi, J.K. 2012. Protein crop production at the northern margin of farming: to boost, or not to boost. Agricultural and Food science 21: 370-383.

Persson, G. 1997. Förädling av vårkorn i Sverige från förr til nu. In: Olsson G. (ed.). Den svenska växtförädlingens historia. Stockholm: Kungliga Skogs- och Lantbruksakademien. p. 187-204. (in Swedish).

Phillips, S.L. \& Wolfe, M.S. 2005. Evolutionary plant breeding for low input systems. Journal of Agricultural Science 143: $245-254$.

R Core Team, 2014. R: A language and environment for statistical computing. R Foundation for Statistical Computing, Vienna, Austria. http://www.R-project.org.

Santos, F.S, Aviani D.M., Hidalgo J.A.F, Machado, R.Z. \& Araújo, S.P. 2012. Evolution, importance and evaluation of cultivar protection in Brazil: the work of the SNPC. Crop Breeding and Applied Biotechnology S2: 99-110.

Schimmelpfennig, D., Pray, C.E. \& Brennan, M. 2004. The impact of seed industry concentration on innovation: a study of U.S. biotech market leaders. Agricultural Economics 30: 157-167.

Silva J.S. 2010. Impact of improved vegetable cultivars in overcoming food insecurity. Euphytica 176:125-136.

Sjödin, J. 1997. Trinsäd. In: Olsson G. (ed.). Den svenska växtförädlingens historia. Stockholm: Kungl. Skogs- och Lantbruksakademien. p 215-222. (in Swedish).

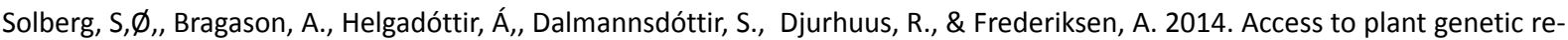
sources for food production in the Arctic. In: Præbel, A. and Groeneveld, L.F. (eds). 2014. Book of Abstracts: Genetic Resources for Food and Agriculture in a Changing Climate. Åsy: The Nordic Genetic Resource Center. p. 72.

Srinivasan, C.S. 2003. Concentration in ownership of plant variety rights: some implications for developing countries. Food Policy 28: $519-546$

Statistics Iceland 2014. Fisheries and agriculture. http://www.statice.is/Statistics/Fisheries-and-agriculture/Agriculture.

Statistics Norway 2011. Jordbruksareal etter bruken.https://www.ssb.no/208059/jordbruksareal-etter-bruken.dekar.

Stoddard, F., Hovinen, S., Kontturi, M., Lindström, K. \& Nykänen, A. 2009. Legumes in Finish Agriculture: history, present status and future prospects. Agricultural and Food Science 18: 191-205.

Stones, R. 2005. Structuration theory. Basingstoke: Palgrave Macmillan. 240 p.

Subbarao GV, Ito, O., Serraj, R., Crouch, J.H., Tobita, S., Okada, K., Hash, C.T., Ortiz, R. \& Berry, W.L . 2005. Physiological perspectives on improving adaptation to drought - Justification for a systemic component-based approach. In Pessaraki M. (ed.). Handbook of photosynthesis, second edition. Boca Raton, Florida: CRC Press, Tayler \& Francis Group. p. 577-594.

Swedish Board of Agriculture 2008. Agriculture in figures years 1866-2007. Jönköping, Sweden. 471 p.

Swedish Board of Agriculture 2013a. Jordbruksstatisisk Årbok 2013. Jönköping, Sweden. 404 p.

Swedish Board of Agriculture 2013b. Certificering av utsäde 2012/2013, Fröburna vekstslag. Jönköping, Sweden. 16 p.

Swedish Board of Agriculture 2014. Certificeringsstatistik 2013 -2014, Fröburna vekstslag. Jönköping, Sweden. 29 p.

UPOV 2014. The International Union for the Protection of New Varieties of Plants. http://www.upov.int.

Vasconcelos, A.C.F., Bonatti, M., Schlindwein, S.L., D’Agostini, L.R., Homem, L.R. \& Nelson, R. 2013. Landraces as an adaptation strategy to climate change for smallholders in Santa Catarina, Southern Brazil. Land Use Policy 34: 250-254.

Åkerman, Å., Nilsson, F., Sylvèn, N. \& Fröier, K. 1951. Svensk växtförädling (Band I and II). Stockholm: Natur och Kultur. 745 and 843 p. (in Swedish). 